\title{
Pelatihan Pembelajaran Era Pendidikan 4.0 Bagi Guru SMP Swasta Kota Padang
}

\author{
Jasrial $^{1}$, Rifma Rusli*)2 \\ ${ }^{12}$ Administrasi Pendidikan/FakultasIlmu Pendidikan/Universitas Negeri Padang \\ ${ }^{*}$ Corresponding author, $\equiv$ rifmar34@fip.unp.ac.id
}

Revisi08/11/2019;

Diterima06/12/2019;

Publish 10/01/2020
Kata kunci:Revolusi Industri 4.0, Kurikulum 3013, PPK, Literasi, HOTS, Teknologi

\begin{abstract}
Abstrak
Guru menjadi aktor penting terlaksananya pembelajaran yang mengacu pada pengembangan kompetensi siswa di era pendidikan 4.0. Permasalahan umum yang ditemukan adalah guru-guru SMP swasta mendapat kesempatan pelatihan lebih rendah dari sekolah negeri baik dan hasil evaluasi pembelajaran menunjukkan kemampuan guru melaksanakan pembelajaran masih cendrung rendah. Rata-rata tingkat capaian siswa per mata pelajaran juga masih rendah. Pelatihan ini bertujuan untuk memberikan pengetahuan dan keterampilan kepada guru SMP swasta Kota Padang dalam melaksanakan pembelajaran efektif dengan mengintegrasikan PPK, literasi, HOTS, dan teknologi digital dalam kurikulum 2013 yang menjadi basis era pendidikan 4.0. Kegiatan ini meliputi penyajian materi tentang: (1) konsep revolusi industri 4.0 dan dampaknya terhadap pelaksanaan pembelajaran, (2) implementasi kurikulum 2013 yang mengacu pada pengembangan kompetensi peserta didik menghadapi revolusi industri 4.0, (3) integrasi PPK dalam pembelajaran, (4) strategi literasi dalam pembelajaran, (5) pembelajaran berbasis HOTS, dan (5) penggunaan teknologi dalammeningkatkanefektivitaspembelajaran.

Metodepelatihan yang digunakan adalah ceramah, diskusi, dan resitasi yang dipandu oleh narasumber dan tim PkM.Peningkatan kemampuan peserta diukurdengan membandingkan hasil evaluasi sebelum dan sesudah pelatihan. Hasil evaluasi akhir menunjukkan terjadinya peningkatan yang signifikan terhadap pemahaman dan keterampilan guru melaksanakan pembelajaranan dengan mengacu pada kompetensi siswa era revolusi industri 4.0.
\end{abstract}

\section{PENDAHULUAN}

\section{AnalisisSituasi}

Pelatihan pembelajaran era pendidikan 4.0 diberikan kepada guru SMP swasta Kecamatan Padang Timur Kota Padang. Kecamatan Padang Timur Kota Padang merupakan salah satu wilayah padat penduduk dan berada di pusat Kota Padang. Pada wilayah ini terdapat 
12 SMP baik negri aupun swasta dengan jumlah peserta didik mencapai 5.431 orang dan 377 orang guru (dapo.dikdasmen.kemendikbud.go.id). Alasan umum pemilihan lokasi dalam usulan ini adalah sekolah swasta cendrung mendapat kesempatan pelatihan lebih rendah dari sekolah negeri baik dari segi waktu maupun kuantitasnya. Padahal dari 7 SMP swasta Kecamatan Padang Timur terdapat 1.333 peserta didik atau $14.22 \%$ dan 101 guru atau $12.9 \%$ dari total peserta didik dan guru tingkat SMP di Kota Padang (dapo.dikdasmen.kemendikbud.go.id).

Untuk memperkuat data di atas, dilakukan penelitian pada salah satu SMP Swasta Kecamatan Padang Timur untuk mendapatkan data persentase guru yang telah mendapatkan pembinaan melalui pelatihan dan tingkat kemampuan guru melakukan pembelajaran berbasis era pendidikan 4.0. Wawancara dengan kepala sekolah (02/04/2019) menyebutkan bahwa semua guru baru mendapatkan pelatihan dan pendampingan kurikulum 2013 kurang lebih tiga bulan yang lalu, dan sampai sekarang proses pendampingan masih tetap berjalan. Padahal SMP tersebut sudah 3 tahun menggunakan kurikulum 2013, dan akan menamatkan lulusan kurikulum 2013 tahun ini. Kepala sekolah melanjutkan, bahwa guru hanya mendapat pembinaan internal dari sekolah melalui supervisi, MGMP, dan lokakarya sekali setahun yang dananya dialokasikan dari BOS. Kepala sekolah mengaku pembinaan tersebut tidak cukup untuk meningkatkan kompetensi guru melakukan inovasi dalam pembelajaran, sementara sekolah tidak mampu untuk melakukan pelatihan dan pengembangan guru dengan dana mandiri.

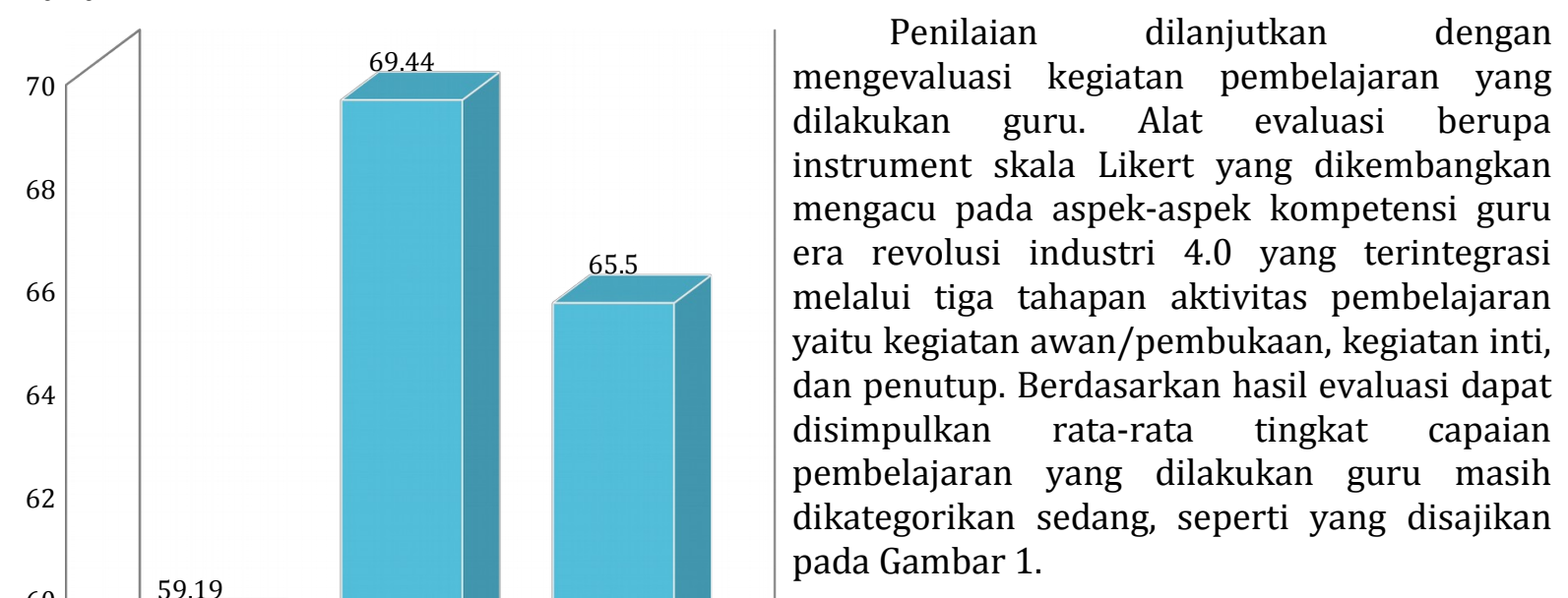


Gambar 1. Grafik Nilai Evaluasi Pembelajaran Guru

Beberapa saat setelahnya dilaksanakan ujian semester ganjil dan rata-rata tingkat capaian siswa per mata pelajaran terutama pada mata pelajaran inti masih sangat rendah. Hal ini menegaskan bahwa kompetensi guru berpengaruh terhadap keberhasilan belajar peserta didik. Secara lebih rinci dapat dilihat pada Gambar 2.

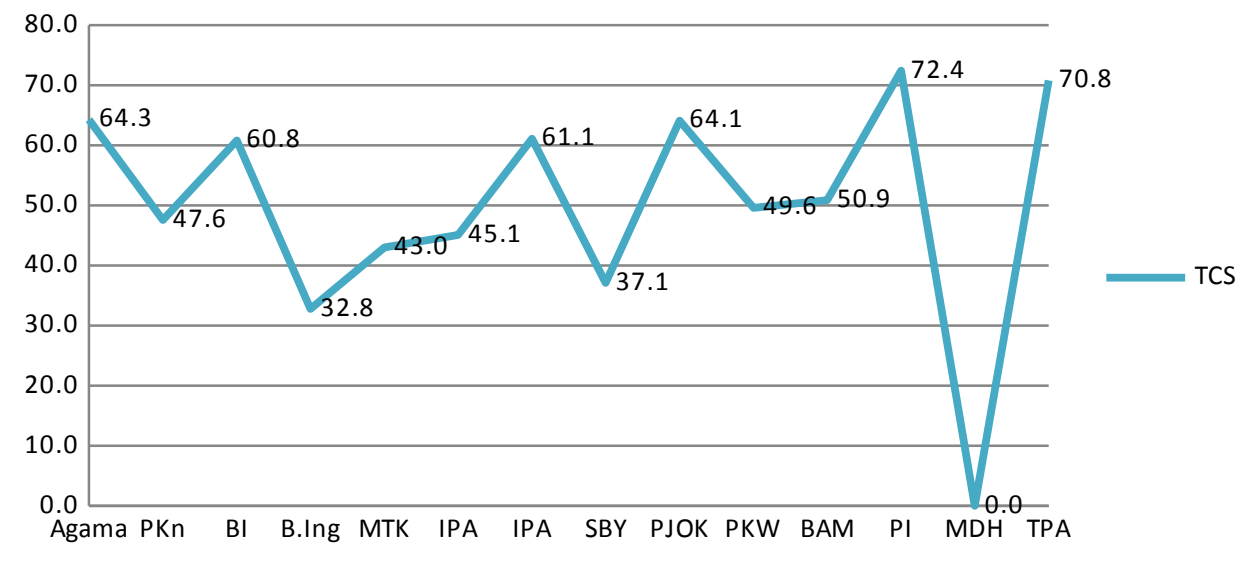

Gambar 2. Tingkat Capaian Siswa dalam Ujian Semester Ganjil TP 2018/2018

Memasuki era revolusi industri 4.0 setiap sistem dan tatanan kehidupan di berbagai bidang harus menyesuaikan diri termasuk bidang pendidikan. Revolusi industri 4.0 adalah era dimana terjadinya kolaborasi teknologi otomatisasi dengan teknocyber yang mengakibatkan dimensi fisik, biologis, dan digital membentuk suatu perpaduan yang saling mengendalikan satu sama lain (Löffler \& Tschiesner, 2013);(Hermann, Pentek, \& Otto, 2016);(Kale, 2016);(Irianto, 2017). Revolusi industri 4.0 merubah cara pandang kita terhadap konsep pendidikan yang akan berpengaruh pada praktek-praktek pengajaran. Era ini menuntut adanya persiapan sistem pembelajaran yang lebih inovatif menyesuaikan dengan perkembangan teknologi (Trilling \& Fadel, 2009).

Mengahadapai tantangan tersebut diperlukan framework pembelajaran abad ke-21 yang mengacukepada: (a) Kemampuan berpikir kritis dan pemecahan masalah (Critical-Thinking and Problem-Solving Skills), (b) Kemampuan berkomunikasi dan bekerjasama (Communication and Collaboration Skills), (c) Kemampuan mencipta dan membaharui (Creativity and Innovation Skills), (d) Literasi teknologi informasi dan komunikasi (Informationand Communications Technology Literacy), (e) Kemampuan belajar kontekstual (Contextual Learning Skills), dan (f) Kemampuan informasi dan literasi media, mampu memahami dan menggunakan berbagai media komunikasi untuk menyampaikan beragam gagasan dan melaksanakan aktivitas kolaborasi serta interaksi dengan beragam pihak(Harjanti, 2018); (Darmajanti, 2017);(Afrianto, 2018);(Farisi, 2016);(Suyati, 2019).

Berdasarkan penjabaran data dan tuntutan pengembangan kompetensi guru era pendidikan 4.0 tersebut, pembinaan kompetensi guru SMP swasta patut menjadi perhatian, mengingat sekolah swasta secara tidak langsung ikut membantu pemerintah menyeleggarakan pendidikan dengan jumlah peserta didik yang tidak sedikit.

\section{Solusi dan Target}

Berdasarkan beberapa permasalahan pembelajaran yang telah dijabarkan pada bagian sebelumnya, maka solusi yang dipilih adalah melakukam "Pelatihan Pembelajaran Era 
Pendidikan 4.0". Materi pelatihan ini berisi tentang: (1) konsep revolusi industri 4.0 dan dampaknya terhadap pelaksanaan pembelajaran, (2) implementasi kurikulum 2013 yang mengacu pada pengembangan kompetensi peserta didik menghadapi revolusi industri 4.0, (3) integrasi Penguatan Pendidikan Karakter (PPK) dalam pembelajaran, (4) strategi literasi dalam pembelajaran, (5) pembelajaran berbasis High Order Thingkin Skill (HOTS), dan (5) penggunaan teknologi dalammeningkatkanefektivitaspembelajaran.

Target yang ditetapkandaripelaksanaanpelatihan ini adalah meningkatkan pengetahuan dan keterampilan guru melaksanakan pembelajaran efektif dengan mengintegrasikan PPK, literasi, HOTS, dan teknologi digital dalam kurikulum 2013 yang menjadi basis era pendidikan 4.0. Kemampuan guru melaksanakan pembelajaran era pendidikan 4.0 ini diharapkan dapat mempersiapkan siswa menjawab tantangan kehidupan di era milenial/revolusi industri 4.0.

\section{METODE PELAKSANAAN}

Tempat dan Waktu

Pelatihaninidilaksanakan di Aula SMP PMT Hamka II Padang pada 24-25 Agustus 2019.

\section{KhalayakSasaran}

Yang menjadikhalayakdalampelatihaniniadalahGuru SMP Swasta Kecamatan Padang Timur Kota Padang.

\section{MetodePengabdian}

Metodeyang digunakan dalampelatihaniniadalah ceramah, diskusi, dan resitasi yang dipandu oleh narasumber dan tim PkM.

\section{IndikatorKeberhasilan}

IndikatorkeberhasilanPkMiniadalahterjadinyameningkatkan pengetahuan dan keterampilan guru melaksanakan pembelajaran efektif dengan mengintegrasikan PPK, literasi, HOTS, dan teknologi digital dalam kurikulum 2013.

\section{MetodeEvaluasi}

Evaluasi kegiatan dilaksanakan 3 kali yaitu sebelum kegiatan inti, pada saat proses, dan sesudah kegiatan. Evaluasi sebelum kegiatan inti dilaksanakan dalam bentuk pretes. Evaluasi proses dilaksanakan dengan mengisi angket yang disiapkan panitia. Sedangkan hasil yang dicapai dilihat dari hasil postes diakhir kegiatan.

\section{HASIL DAN PEMBAHASAN}

\section{Deskripsi Kegiatan PKM}

Sebelum pelatihan dimulai peserta diberikan pretes untuk mengukur pemahamannya terhadap beberapa meteri yang berhubungan dengan pembelajaran era pendidikan revolusi industri 4.0 (data ini disajikan pada bagian B). Gambaran pelaksanaan Iptek yang telah ditransfer kepada mitra adalah sebagai berikut.

\section{Revolusi Industri 4.0 Dan Dampaknya Terhadap Pembelajaran}

Revolusi industri 4.0 dan dampaknya terhadap pembelajaran disampaikan oleh Dr. Darmasyah, M.Pd selama 3 jam. Materi ini disajikan di awal dalam rangka memperkuat pemahaman kepala sekolah dan pengawas tentang revolusi industri 4.0 dan bagaimana pengaruhnya terhadap pembelajaran. Secaraumummenghadapirevolusi industry 4.0, Pendidikan harus focus pada pembenahan: learning environment, professional development, 
curriculum instruction,standards and assessment(Maemunah, 2018); (Ghufron, 2018); (Kemeristekdikti, 2018).

Sebelum memulai pemaparan materinya, pemateri mencoba mengukur tingkat pemahaman peserta pelatihan dengan melontarkan beberapa pertanyaan dasar terkait materi. Dari pertanyaan yang dilontarkan pemateri tidak banyak peserta yang mampu menjawab dengan baik. Dari jawaban yang diberikan peserta, sesekali pemateri mencoba memperbaiki konsep yang selama ini dipegang oleh peserta pelatihan.Materi ini disampaikan dengan menggunakan metode ceramah dan diselingi dengan tanya jawab.

Materi literasi dan pemanfaatan teknologi digitan dalam pembelajaran disampaikan oleh Dr. Ulfia Rahmi, M.Pd selama 4 jam. Penyajian materi dimulai dengan penjelasan tentang konsep dan trategi literasi dalam pembelajaran. Literasi dan teknologimerupakaduakomponenpentingdalampembelajaran era revolusi industry 4.0. pada era iniinitidakcukupdihadapihanyadenganlierasi lama sepertimembaca, menulis, dan matematika. Guru perlumenggunakanliterasibaruterkaitdenganliterasi data, lietrasiteknologi dan literasimanusia. Terkaitdenganteknologi, guru sudahharusmerubahparadigma lama dariICT as objectmenjadiICT as tool(Kemeristekdikti, 2018);(Afrianto, 2018);(Farisi, 2016).

Penyampaian materi dilanjutkan dengan terlebih dahulu meminta para kepala sekolah untuk mengemukakan bagaimana penyusunan program literasi yang telah di lakukan kepala sekolah dan guru selama ini. Materi dilanjutkan pada penjelasan macam-macam literasi termasuk literasi digital serta pemanfaatannya dalam pembelajaran yang akan dimasukkan ke dalam program literasi. Diakhir penyajian materi kedua ini, peserta pelatihan ditugaskan untuk menyusun satu program literasi. Kegiatan ini dilaksanakan dengan metode penugasan (resitasi), studi dokumentasi, dan diskusi.

Implemtasi Kurikulum 2013 yang Mengacu pada Pengembangan Kompetensi Peserta Didik Menghadapi Revolusi Industri 4.0

Materi implementasi kurikulum 2013 yang mengacu pada pengembangan kompetensi peserta didik menghadapi revolusi industry 4.0 disampaikan oleh Dr. Abna Hidayati, M.Pd selama 3 jam. Materi ini bertujuan untuk memberikan pemahaman dan keterampilan kepada kepala sekolah dan guru untuk merencanakan, mengimplementasikan, dan mengevaluasi kurikulum 2013 yang relevan dengan kompetensi-kompetensi yang dibutuhkan untuk menghadapi revolusi Industri 4.0. Materi ini disampaikan dengan metode ceramah, penugasan (resitasi) dan diskusi. Penugasan yang diberikan adalah RPP dan LKPD beberapa materi dalam kurikulum 2013.

\section{Penguatan Pendidikan Karakter (PPK)}

Materi integrase PPK disampaikan oleh Dr. Rifma, M.Pd selama 4 Jam. Kegiatan ini diawali dengan mengupgrading pemahaman dan sikap guru terhadap implementasi pendidikan karakter di sekolah. Selanjutnya penjelasan materi dimulai dengan konsep dasar PPK di sekolah, dan dilanjutkan dengan strategi-strategi implementasi PPK di sekolah. Revolusiindustriharusdilandasikarakterkerja dan karakterpribadi yang melandasicaraberfikir, meyakini, dan bersikap. Revolusiindustri 4.0 harusdiimbangidengansistem Pendidikan yang mengkonkritkanpengalamanbelajar yang dapatmeningkatkankemampuankomunikasi, kolaborasi, berfikirkritis, kreatif, dan inovati yang dilandasidenganakhlak dan nilai-nilai moral yang baik(Suwardana, 2018);(Iswan dan Herwina, 2018);(Tulim, 2018).

Penyampaian materi inidilakukan dengan metode ceramah, penugasan (resitasi) dan diskusi. Penugasan yang diberikan adalah: menganalisis nilai-nilai PPK yang dapat 
dikembangkan melalui aktivitas pembelajaran dalam RPP dan LKPD kurikulum 2013 yang telah disusun pada tahap pelatihan (penyampaian materi) sebelumnya.

\section{High Order Thingkin Skill (HOTS)}

Materi HOTS disampaikan oleh Dr. Jasrial, M.Pd selama 3 jam. Materi ini dipilih dengan tujuan agar kepala sekolah dan guru mampu menganalisis proses dan evaluasi pembelajaran berbasis HOTS. Sebelum memulai pemaparan materinya, pemateri mencoba mengukur tingkat pemahaman peserta pelatihan dengan melontarkan beberapa pertanyaan dasar terkait materi tersebut. Dari pertanyaan yang dilontarkan pemateri tidak banyak peserta yang mampu menjawab dengan baik. Dari jawaban yang diberikan peserta, sesekali pemateri mencoba merubah paradigma peserta pelatihan yang telah terbiasa dengan proses dan target pembelajaran yang belum mempu meningkatkan HOTS Peserta didik. Materi ini disampaikan dengan menggunakan metode ceramah dan diselingi dengan tanya jawab.

\section{Hasil yang Diperoleh}

Hasil yang telah diperoleh darikegiatanini adalah data Tingkat CapaianResponden (TCR)darihasilpretest dan posttestsetiap sekolah yang disajikanpada Gambar3 dibawah ini.

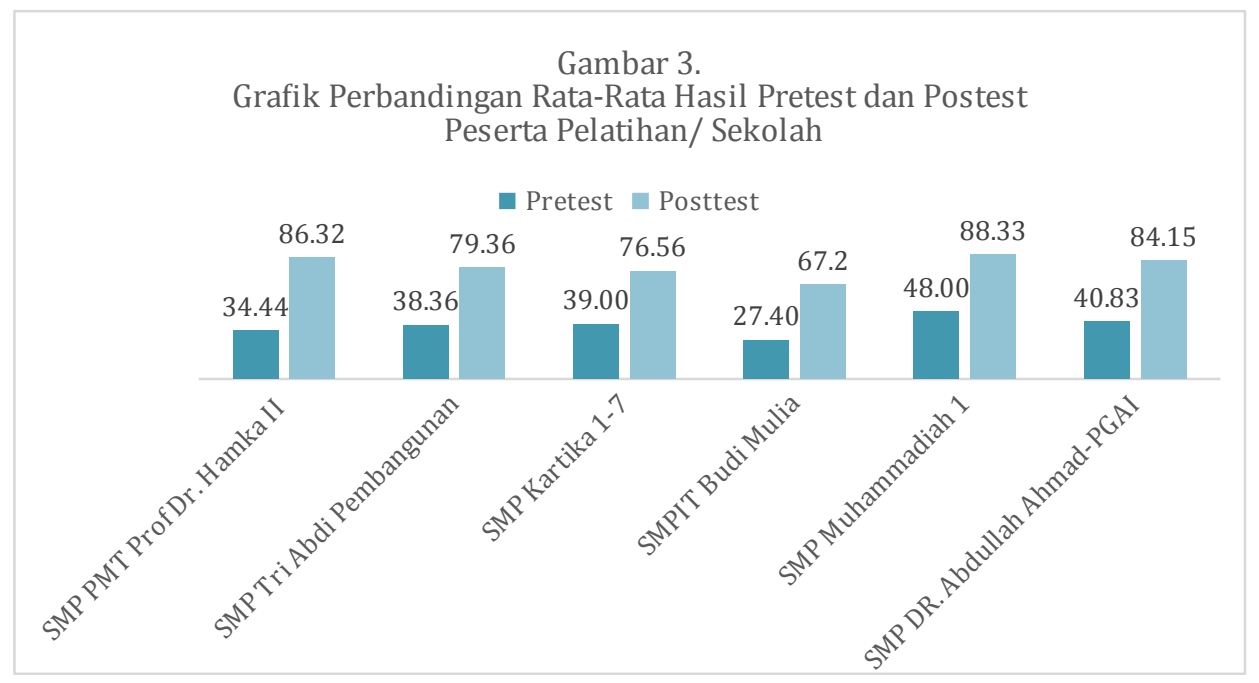

Gambar 3. Tingkat PemahamanPesertaPemahamanPeserta

Data pada Gambar 3 menunjukkan tingkatpemahaman peserta pelatihan terkait revolusi industri 4.0 dan aspek-aspek pembelajaran yang terkait dengannyasebelum dan sesudahdiberikanpelatihan.Berdasarkan data pada Gambar 3 di atas, dapatdisimpulkanterjadinyapeningkatan yang signifikanterhadappengetahuan dan pemahaman guru terhadapmateripelatihan.Peningkatan rata-rata hasil pretest dan posttest pesertasecaraumum di pengaruhi oleh faktorkeseriusan dan antusiasmepesertauntukmengekplorasiinformasidenganaktifbertanyakepadanarasumber.

Disampingitu, kemampuannarasumberdalammenyampaikanmateridengan style yang menyengangkan dan contoh-contoh yang operasionalsemakinmeningkatkanmotivasipesertamengikutipelatihan.

\section{KESIMPULAN}


Pengabdiankepadamasyarakatdenganjudul "PelatihanPembelajaran Era Pendidikan 4.0 bagi guru SwastaKecamatan Padang Timur" telahdilaksanakandi Aula SMP PMT Hamka II Padang pada 24-25 Agustus 2019. Pelatihan dimulai dengan memberikan pretest untuk mengukur pengetahuan dan pemahaman peserta terhadap beberapa meteri yang berhubungan dengan pembelajaran era pendidikan revolusi industri 4.0. Kegiatan dilanjutkan dengan penyampaian materi oleh narasumber dengan metode ceramah, diskusi, dan resitasi yang dipandu oleh narasumber dan tim PkM.Diakhirkegiatandilakukan posttest untukmengkurtingkatkeberhasilan program/pelatihan oleh peserta. Hasil posttest menunjukkanterjadinyapeningkatan yang signifikanterhadappengetahuan dan pemahaman guru terhadapmateri-materipelatihan yang telahdiberikan.

\section{DAFTAR PUSTAKA}

Afrianto. (2018). Being a professional teacher in the era of industrial revolution 4.0: Opportunities, challenges and strategies for innovative classroom practices. English Language Teaching and Research.

Darmajanti, P. (2017). The importance of teaching strategic competence for Indonesian learner. Asian EFL Journal.

Farisi, M. I. (2016). Developing the 21st-century social studies skills through technology integration. Turkish Online Journal of Distance Education. https://doi.org/10.17718/tojde.47374

Ghufron, M. A. (2018). Revolusi industri 4.0: Tantangan, Peluang dan Solusi Bagi Dunia Pendidikan. Seminar Nasional Dan Diskusi Panel Multidisiplin Hasil Penelitian Dan Pengabdian Kepada Masyarakat.

Harjanti, M. H. (2018). The Implementation Of The 21th Century Competency For Elementary School Teachers At Curriculum 2013 Training Central Java Province Year 2017. Social, Humanities, and Educational Studies (SHEs): Conference Series. https://doi.org/10.20961/shes.v1i1.23726

Hermann, M., Pentek, T., \& Otto, B. (2016). Design principles for industrie 4.0 scenarios. Proceedings of the Annual Hawaii International Conference on System Sciences. https://doi.org/10.1109/HICSS.2016.488

Irianto, D. (2017). INDUSTRY 4.0 The Challenges of Tomorrow. Seminar Nasional Teknik Industri 2017 - Batu-Malang.

Iswan dan Herwina. (2018). Penguatan Pendidikan Karakter Perspektif Islam dalam Era Millenial IR. 4.0. Seminar Nasional Pendidikan Era Revolusi "Membangun Sinergitas Dalam Penguatan Pendidikan Karakter Pada Era IR 4.0."

Kale, A. (2016). How the Fourth Industrial Revolution Will Impact Our Lives.

Kemeristekdikti. (2018). Pengembangan Iptek dan Pendidikan Tinggi di Era Revolusi Industri 4.0. Ristekdikti.

Löffler, M., \& Tschiesner, A. (2013). The Internet of Things and the future of manufacturing. McKinsey on Business Technology. https://doi.org/10.1201/b19296-12

Maemunah. (2018). Kebijakan pendidikan pada era revolusi industri 4.0. Prosiding Seminar Nasional Pengambdian 2018 Univeristas Muslim Nusantara Al-Washliyah.

Suwardana, H. (2018). Revolusi Industri 4. 0 Berbasis Revolusi Mental. Jati Unik: Jurnal Ilmiah Teknik Dan Manajemen Industri. https://doi.org/10.30737/jatiunik.v1i2.117

Suyati. (2019). Meningkatkan Peranan Guru Profesional Dalam Menghadapi Era Revolusi Industri 4.0. Prosiding Seminar Nasional Pendidikan Program Pascasarjana Universitas Pgri Palembang.

Trilling, B., \& Fadel, C. (2009). What is 21st Century Learning? 21st Century Skills: Learning for Life in Our Times.

Tulim, A. (2018). Penguatan Pendidikan Karakter Perspektif Manajemen Dalam Era Millenial 
Suluah Bendang: Jurnal Ilmiah Pengabdian Kepada Masyarakat Vol.20, No.1,2020

Jasrial, Rifma

Industri 4.0. Prosiding Seminar Nasional Era Industri (SNEI). 